\title{
The hydroxychloroquine alliance: how far-right leaders and alt-science preachers came together to promote a miracle drug
}

\author{
Guilherme Casarões ${ }^{1}$ \\ David Magalhães ${ }^{23}$ \\ 1 Fundação Getulio Vargas / Escola de Administração de Empresas de São Paulo, São Paulo / SP - Brazil \\ 2 Pontifícia Universidade Católica de São Paulo, São Paulo / SP - Brazil \\ ${ }^{3}$ Fundação Armando Álvares Penteado, São Paulo / SP - Brazil
}

Soon after the outbreak of the COVID-19 pandemic, the world saw far-right leaders uniting to promote hydroxychloroquine despite controversial results. Why have some leaders actively promoted the drug since then, contradicting recommendations made by their own government's health authorities? Our argument is twofold. First, hydroxychloroquine has been an integral tool of medical populist performance in the context of the COVID-19 pandemic. We adopt Lasco \& Curato's (2018) definition of medical populism as a political style based on performances of public health crises that pit 'the people' against 'the establishment' using alternative knowledge claims to cast doubt on the credibility of doctors, scientists, and technocrats. Second, rather than being an individual endeavor, medical populism addressing the coronavirus crisis has led populists to build an alt-science network. We define it as a loose movement of alleged truth-seekers who publicly advance scientific claims at a crossroads between partial evidence, pseudo-science, and conspiracy theories. It comprises scientists, businesspeople and celebrities united by their distrust of governments and mainstream science. In this article, we look at how the hydroxychloroquine alliance was formed, as well as its political and policy implications. To this end, we compare why and how Donald Trump and Jair Bolsonaro have appealed to medical populist performances when addressing the health crisis. By mobilizing the concepts of medical populism and alt-science, this paper aims to contribute to the scholarship on the relationship between populist politics and policy-making.

Keywords: COVID-19; populism; public health; far-right; alt-science; Bolsonaro.

\section{A aliança da hidroxicloroquina: como líderes de extrema direita e pregadores da ciência alternativa se reuniram para promover uma droga milagrosa}

Logo após a eclosão da pandemia da COVID-19, o mundo viu líderes de extrema direita se unindo para promover a hidroxicloroquina (HCQ), apesar de resultados controversos. Por que alguns líderes promoveram ativamente o remédio desde então, mesmo contradizendo recomendações de autoridades de saúde de seus próprios governos? Nosso argumento é duplo. Primeiro, a HCQ tem sido uma ferramenta integral do desempenho médico populista no contexto da pandemia de COVID-19. Adotamos a definição de Lasco e Curato (2018) de populismo médico como um estilo político performático durante crises de saúde pública que joga "o povo" contra "o sistema" usando alegações de conhecimento alternativo para lançar dúvidas sobre a credibilidade de médicos, cientistas e tecnocratas. Segundo, em vez de ser um esforço individual, o populismo médico diante da crise do coronavírus levou populistas a construir uma rede de ciência alternativa, definida como um movimento difuso de supostos buscadores da verdade que defendem publicamente suas convicções científicas em uma encruzilhada entre evidências parciais, pseudociência e teorias da conspiração. É composto por cientistas, empresários e celebridades unidos por sua desconfiança nos governos e na ciência convencional. Neste artigo, examinamos a formação da aliança da hidroxicloroquina, bem como suas implicações políticas e para as políticas públicas. Para tanto, comparamos por que e como Donald Trump e Jair Bolsonaro recorreram ao populismo médico performático ao abordar a crise de saúde. Ao mobilizar os conceitos de populismo médico e ciência alternativa, este artigo tem como objetivo contribuir para o estudo da relação entre política populista e formulação de políticas.

Palavras-chave: COVID-19; populismo; saúde pública; extrema direita; ciência alternativa; Bolsonaro. 


\section{La alianza de la hidroxicloroquina: cómo los líderes de extrema derecha y los predicadores de la ciencia alternativa se unieron para promocionar una droga milagrosa}

Poco después del comienzo de la pandemia de COVID-19, el mundo vio a líderes de ultraderecha uniéndose para promover la hidroxicloroquina (HCQ) a pesar de sus controvertidos resultados. ¿Por qué algunos líderes han promocionado activamente la medicina desde entonces, incluso contradiciendo las recomendaciones de las autoridades de salud de sus propios gobiernos? Nuestro argumento es doble. Primero, la HCQ ha sido una herramienta integral de la performance del populismo médico en el contexto de la pandemia de COVID-19. Adoptamos la definición de Lasco y Curato (2018) de populismo médico como un estilo político performativo durante crisis de salud pública que pone al pueblo contra el sistema (establishment) usando alegaciones de conocimiento alternativo para poner en duda la credibilidad de médicos, científicos y tecnócratas. Segundo, en lugar de ser un esfuerzo individual, el populismo médico ante la crisis del coronavirus ha llevado a los populistas a construir una red de ciencia alternativa, definida como un movimiento difuso de supuestos buscadores de la verdad que defienden públicamente sus convicciones científicas en una encrucijada entre evidencias parciales, pseudociencia y teorías de la conspiración. Son científicos, empresarios y celebridades unidos por su desconfianza hacia los gobiernos y la ciencia convencional. En este artículo, analizamos cómo se formó la alianza de la hidroxicloroquina, así como sus implicaciones políticas y para las políticas públicas. Comparamos por qué y cómo Donald Trump y Jair Bolsonaro han recurrido al populismo médico performativo al abordar la crisis de salud. Al movilizar los conceptos de populismo médico y ciencia alternativa, este artículo tiene como objetivo contribuir a la investigación sobre la relación entre la política populista y la formulación de políticas.

Palabras clave: COVID-19; populismo; salud pública; ultraderecha; ciencia alternativa; Bolsonaro.

\section{INTRODUCTION}

Between mid-March and April, the world witnessed some statesmen uniting around the promotion of hydroxychloroquine (HCQ), an anti-malarial medicine purportedly efficient in treating COVID-19 patients. It all began on March 19, when Donald Trump came out to hail the drug (taken together with azithromycin) as having "a real chance to be one the greatest game changers in the history of medicine". In the week that followed, loyal allies like Jair Bolsonaro (Ministério da Saúde, 2020) and Benjamin Netanyahu (Efrati, 2020) started touting HCQ locally and ordered their own medical authorities to include the drug into national treatment protocols.

Those leaders' enthusiasm sparked a widespread scramble for hydroxychloroquine around the world. India, whose Council on Medical Research had asked health personnel and suspected cases to take HCQ as prophylactic as early as March 22, made it harder to buy the drug and imposed an export ban a few days later to prevent shortages at home (Reuters, 2020a). Hungary immediately followed suit, banning HCQ exports after declaring it a "strategic drug" on March 25 (Reuters, 2020b). As more countries embraced hydroxychloroquine therapies for COVID-19, the world seemed divided between a few pharmaceutical powers that held the key to overcoming the pandemic and several countries craving for a miraculous medicine.

That might seem a bit over the top for a drug whose therapeutic benefits were (and still are) unclear. Despite several studies and reports (Kupferschmidt, 2020), the use of HCQ has been controversial from the outset, mostly given the risks of arrhythmia and other cardiac illnesses. Why, then, have some leaders actively touted the drug, even when it ran counter to recommendations made by their own government's health authorities? 
Our argument is twofold. First, HCQ has been an integral tool of medical populist performance in the context of the COVID-19 pandemic. We adopt Lasco and Curato's (2018) definition of medical populism as a political style based on performances of public health crises that pit 'the people' against 'the establishment' using alternative knowledge claims to cast doubt on the credibility of doctors, scientists, and technocrats. Countering expectations that populists would either moderate their positions or get completely discredited in their response to the pandemic (Zabala, 2020), hydroxychloroquine promotion has allowed prominent far-right populist leaders to increase - or, at least, to maintain - their popularity at home.

Second, rather than being an individual endeavor, medical populism addressing the coronavirus crisis has led populists to build an alt-science network that serves as a platform for doctors, lobbyists, businesspeople, and religious leaders who are - or have become - linked to far-right movements across the world. Although there is no scholarly discussion of alt-science as of yet (see Engber, 2017; Waldman, 2017), we define it as a loose movement of alleged truth-seekers who publicly advance scientific claims at a crossroads between partial evidence, pseudo-science, and conspiracy theories. It comprises groups as diverse as maverick scientists, wealthy donors, flat-earthers, anti-vaxxers, and climate deniers, all united by their distrust of governments and mainstream science. While this is not to say that alt-science positions are intrinsically wrong or misleading, their political nature has been exploited by populists in their battle against the medical establishment.

In the world of far-right populists, the United States and Brazil are the two countries where the alt-science network around the promotion of HCQ came full circle - with presidents, politicians, media outlets, businesspeople, religious leaders, and scientists joining forces to advocate a fast and effective solution for the COVID-19 pandemic. In this article, we look at how the hydroxychloroquine alliance was formed, as well as its political and policy implications, both domestically and internationally. To this end, we compare why and how Donald Trump and Jair Bolsonaro have appealed to medical populist performances when addressing the health crisis. By mobilizing the concepts of medical populism and alt-science, this paper aims to contribute to the scholarship on the relationship between populist politics and policy-making.

\section{POPULISM, HEALTH POLICY, AND THE COVID-19 PANDEMIC}

We define populism as "a thin-centered ideology that considers society to be ultimately separated into two homogeneous and antagonistic camps, "the pure people" versus "the corrupt elite," and which argues that politics should be an expression of the volonté générale (general will) of the people (Mudde \& Kaltwasser, 2017, p. 6). However, because "the people" is an empty signifier, it makes populism a powerful political ideology and phenomenon, as it frames the idea of "the people" to generate a shared identity between different groups and facilitate their support for a common cause (Laclau, 2005).

Populism conveys "the people" in three different ways: (1) the people as the source of sovereignty, from which political power stems; (2) the people as a constituent of a national identity (or a nation); (3) the people as the source of conventional wisdom, of 'common sense.'The third meaning is the one we will adopt in this article. It combines socioeconomic status with cultural and popular traditions. As it praises the average man, populism repudiates the prevailing cultural mainstream, which snubs the tastes, interests, and values of the ordinary citizen. Opposing such an 'elitist' worldview, bringing 
the average man back onto the political stage is a way to restore dignity, the popular wisdom, and the traditional knowledge of groups that have been sidelined from power thanks to their cultural or economic status (Mudde \& Kaltwasser, 2017).

This anti-elitist burst reveals populism's suspicion and rejection of social and political gatekeepers, such as political parties, big corporations, bureaucracies, mainstream media, or any other that could distort the authentic and organic connection between the populist leader and the "common people". Therefore, such an idea of the elite also encompasses the scientific community, universities, prestigious research institutes, the pharmaceutical industry, and even public health officials (Greer, 2017).

Populists' demonization of science has profound effects on healthcare policies. Parmet (2010) has shown, for one, that populist behavior undermined the efficacy of the H1N1 vaccination campaign in the United States as it fueled conspiracy theories and exacerbated distrust of health professionals. More recently, Lasco and Curato (2018) have put forward the concept of medical populism to characterize a style of leadership that pits 'the people' against 'the establishment' in addressing health emergencies. Medical populists oppose traditional technocratic responses by politicizing, simplifying, and spectacularizing complex public health issues.

When the COVID-19 pandemic broke out and rapidly spread across the world, some analysts rushed to predict that populist leaders would not be able to tackle the crisis. Populism could become the first "ideological casualty" of the new coronavirus, since "regimes headed by populists are now facing a barrage of criticism that they cannot manage to divert or neutralize" (Paracha, 2020). Therefore, the populist war on civil servants, experts, and scientific communities would quickly take its toll on leaders distrustful of science (Harris, 2020). Also, populists face the growing risk of being exposed for who they are, "incompetent leaders who do little more than satisfy the interests of narrow business circles around them, while leaving their nations to economic precarity and social insecurity" (Zabala, 2020).

However, rather than being stopped by the outbreak, some populists have doubled down on their divisive, anti-elitist, and potentially authoritarian rhetoric (Müller, 2020). Medical populism has allowed leaders to pit 'the people' against 'the establishment' by sowing several cleavages in society: between professionals who can work from home and factory workers who cannot; between the elderly who cannot go outside and the young who are being kept inside by government decree; and between formal workers who receive wage subsidies and the self-employed who have lost all income (Velasco, 2020). Also, the pandemic has both heightened fears of "the other" and emboldened politicians to pursue long-desired policies that would have been difficult without the pandemic (Abdelal, 2020), from brutal police repression (as in the Philippines) to tight control of movement (as in India), from attacking political institutions (as in Brazil and Israel) to shutting them down (as in Hungary).

Whereas the diversity of populist responses to the pandemic makes it hard to predict whether "populism" will come out stronger or weaker of the health crisis (Mudde, 2020), the impacts on policy tend to be long-lasting. By empowering alt-science advocates and forging far-right transnational networks, populists like Donald Trump, Jair Bolsonaro, Narendra Modi, and Benjamin Netanyahu have attempted to improve their positions at home and abroad at the expense of mainstream science and national and international health authorities. The most visible face of this process was the early promotion of hydroxychloroquine as a public health panacea. Despite promising results, it has dismissed World Health Organization recommendations (WHO, 2020), ignored medical 
recommendations (Palmeira et al., 2020), and gained political overtones that have muddied the scientific debate (O’Connor \& Weatherall, 2020; Wessel, 2020).

\section{THE FORGING OF THE HYDROXYCHLOROQUINE ALLIANCE}

Although reports of clinical trials of chloroquine and hydroxychloroquine against COVID-19 date back to early February in China (Subramanian, 2020), their potential to tackle the pandemic only came to public knowledge several weeks later. On March 11, an Australian entrepreneur living in China, a Bitcoin investor and law school graduate, and a self-described philosopher pinned hope on the healing powers of a "miraculous drug" in a Twitter thread (Nguyen, 2020). A couple of days later, two of them co-authored and published a Google Docs paper making the case for chloroquine, which caught the eye of Silicon Valley businesspeople and conservative media outlets. On March 16, Tesla and SpaceX CEO Elon Musk tweeted a link to that paper suggesting that the anti-malarial drug chloroquine might be effective at treating COVID-19. The document linked by Musk was later removed from Google Docs for violating the company's terms of service.

On that same day, French microbiologist Didier Raoult released the results of a small clinical trial that purportedly showed a 100 percent cure rate. The paper suggested that a combination of hydroxychloroquine and the anti-bacterial medication azithromycin could be effective against COVID-19 (Gautret et al., 2020). On March 18, Gregory Rigano, one of the authors of the paper Musk had tweeted about, appeared on Laura Ingraham's Fox News show to promote his paper. They took the opportunity to tout Raoult's study, reinforcing the alt-science case for HCQ.

Why alt-science? First of all, despite his bold claims on HCQ efficacy, Raoult's paper was harshly criticized in scientific circles for lack of methodological rigor (Grens, 2020). The day it was released, March 16, Anthony S. Fauci, one of the three members of President Trump's Coronavirus Taskforce, said on the very same Fox News show that the study was 'anecdotal' from a scientific standpoint (Gabler \& Keller, 2020).

Second, the main characters involved in the early promotion of chloroquine - Raoult, Rigano, and Musk - hold a track-record of scientific controversies. The French doctor, a populist in his own merit, has often used his popularity on social networks to criticize politicians and scientists (Sayare, 2020), to promote climate skepticism (Raoult, 2013) and even to question the theory of evolution (Raoult, 2011). Rigano sparked controversy by claiming his pro-HCQ paper had been produced in consultation with the Stanford School of Medicine, which was later rebutted (Gallagher, 2020). Musk, once thought of as an environmental visionary, took a far-right turn - or, in his own words, "took the red pill" - as the pandemic broke out. On March 6, Musk's infamous tweet "the coronavirus panic is dumb" (Musk, 2020) drew him closer to Trump and his supporters (Sanches, 2020). The three were later joined by celebrity surgeon and TV show host $\mathrm{Dr}$. Mehmet $\mathrm{Oz}$, who became the most prominent medical voice advocating HCQ on Fox News and elsewhere (Caulfield, 2020).

On March 19, the hydroxychloroquine alliance was finally set in motion as Donald Trump stepped up to declare, against his own top health advisor, that "chloroquine and hydroxychloroquine" had shown "very, very encouraging" early results. Eager to jump on Trump's bandwagon, Brazilian president Jair Bolsonaro quickly (and enthusiastically) embraced the antimalarial elixir as a potential cure' for COVID-19 patients. On March 21, two days after the U.S. president mentioned HCQ for the 
first time, Bolsonaro published a video on his social networks announcing that he had ordered the Army Laboratory to ramp up chloroquine production and Agência Nacional de Vigilância Sanitária (ANVISA) to ban the drug's exports. He added that the Albert Einstein Israelite Hospital - Latin America's best, where Bolsonaro was treated after being stabbed on the eve of the 2018 elections - had started clinical trials with very promising prospects (Bolsonaro, 2020a).

\section{CASE STUDIES OF MEDICAL POPULIST RESPONSES TO COVID-19}

Trump and Bolsonaro's hydroxychloroquine advocacy may be explained as part of a medical populist performance. Both presidents wanted to dodge criticism on their early denial of the coronavirus's gravity by politicizing the pandemic and offering the public a quick fix that seemed promising enough to justify its adoption despite lack of solid evidence. They also sought to strengthen their positions by joining forces with each other, on the one hand, and by amassing domestic support among prominent doctors and businesspeople, conservative politicians and media, and religious leaders, on the other. At the end of the day, foreign policy and health policies were directly impacted by this global medical populist response to COVID-19. In the following section, we will compare how those strategies have played out in the United States and Brazil.

\subsection{The United States}

Besides his populist, anti-intellectual and anti-scientific traits (Goodman, 2019), Trump's attitudes towards HCQ may be understood by a short-term political calculation related to the November elections. The Trump administration's positive economic record was one of his strongest electoral assets - just before the coronavirus swept across the U.S. and destroyed more than 20 million jobs between March and May (Morath, 2020). That explains why Trump's first reaction before the COVID-19 threat was to deny the gravity of the disease and criticize social distancing measures. While Trump has often boasted publicly that he had the situation under total control since the first COVID-19 was confirmed in the U.S., on January 21, he would only issue social distancing guidelines in mid-March (The White House, 2020).

As the U.S. economy plummeted and unemployment insurance claims hit a record high, the appearance of a 'miraculous drug' could be Trump's redemption as the presidential race drew near. Drawing on Raoult's updated study, published in the International Journal of Antimicrobial Agents on March 21, the U.S. president began touting the combination of hydroxychloroquine and azithromycin as "one of the biggest game changers in the history of medicine" (Trump, 2020a). A few days later, the International Society of Antimicrobial Chemotherapy (ISAC), which is responsible for the journal where Raoult's research had been put out, issued a note saying the publication "does not meet the expected standard, especially relating to the lack of better explanations of the inclusion criteria and the triage of patients to ensure patient safety" (ISAC, 2020).

Early evidence of HCQ use against COVID-19 was promising but feeble. To prevent people from scrambling for the drug, immunologist Anthony Fauci, longtime director of the National Institute of Allergy and Infectious Diseases (NIAID) and one of the lead members of the White House Coronavirus Task Force, dismissed hydroxychloroquine benefits as 'anecdotal' in a plea for caution 
(Flaherty \& Phelps, 2020). Yet, Trump kept pushing the antimalarial drug. He ordered the Food and Drug Administration (FDA) to lift the ban on products from two of the local plants of India's Ipca Laboratories, which had been charged with data manipulation, so that raw materials and HCQ tablets could be shipped to the U.S. (Palmer, 2020).

Trump's sense of urgency led him to clash publicly with his top COVID-19 adviser. "I think Tony [Fauci] would disagree with me - but the reason I disagree with you is that we have a pandemic. We have people dying now." (Trump, 2020b) The U.S. president was playing the card of what London and Kimmelman dubbed "pandemic research exceptionalism", meaning that a public health crisis sometimes demands exceptions to high standards for quality, such as large randomized controlled trials. However, the authors argue that "rather than generating permission to carry out low-quality investigations, the urgency and scarcity of pandemics heighten the responsibility of key actors in the research enterprise to coordinate their activities to uphold the standards necessary to advance this mission" (London \& Kimmelman, 2020).

As the clinical success of HCQ was a matter of political survival for Trump, he started a race against the clock. A week after his first tweet on hydroxychloroquine, the FDA issued an emergency authorization for experimental coronavirus treatments with the antimalarial drug. In the days that followed, the president reached out to business groups and the pro-Republican media. At a meeting with Oracle's chairman Larry Ellison, who had recently hosted a fundraising event for Trump's reelection campaign in California, they suggested creating a system based on Oracle's database tools to track the use of chloroquine and hydroxychloroquine in COVID-19 treatments. In order to increase HCQ stocks at home, the U.S. government received donations from Novartis AG (30 million doses of hydroxychloroquine) and Bayer AG (1 million doses of chloroquine) (Edney, 2020).

Fox News has also joined Trump's HCQ campaign. As Walker and Gogarty (2020) found, Fox News touted the drug approximately 300 times, between March 23 and April 6. Most mentions were made in popular shows as The Ingraham Angle (84 times), Fox \& Friends (76 times), Hannity (53), and Tucker Carlson Tonight (22) (Gogarty \& Walker, 2020). Trump has gone as far as having host Laura Ingraham and two physicians at the White House to promote HCQ (Washington Post, 2020).

On April 4, as the global crisis worsened and the demand for HCQ went through the roof, India's Directorate General of Foreign Trade imposed a blanket ban on hydroxychloroquine and its formulations (Suneja, 2020), which would cut off half of U.S.s supplies of the drug (Bloomberg, 2020). Since malaria is one of the country's major public health problems, India holds the lion's share of the hydroxychloroquine production market - manufacturing about 70 percent of the world's supply and exports $\$ 50$ million worth of it every year (Balasubramanian, 2020). A few weeks before, Indian prime-minister Narendra Modi had already announced restrictions on exports, except on humanitarian grounds or for those who had made their advance payments in full.

At his daily briefing later that day, Trump said that he had spoken with Modi, asking him to release the amounts of HCQ the United States had ordered. Although there seemed to be nothing unusual with the reference to the Indian prime-minister, it was clear that Trump sought to raise the tone of his public appearances, as he admitted up to 200,000 people could die from the epidemic and added that his government would retaliate if "people" did not give Americans the masks they had bought (Trump, 2020). Modi promptly responded on his Twitter account: "Had an extensive telephone 
conversation with President @realDonaldTrump. We had a good discussion, and agreed to deploy the full strength of the India-US partnership to fight COVID-19" (Modi, 2020).

But tides turned for India in a couple of days. In another press briefing, Trump said he would retaliate against Modi if he kept withholding supplies of HCQ for which the U.S., Brazil and other countries had placed advance orders: "If he doesn't allow it to come out, that would be okay, but, of course, there may be retaliation. Why wouldn't there be?" (Trump, 2020c). The US president's threat caused shock and awe among the Indian public, since both populist radical right leaders enjoyed a blossoming relationship and had recently exchanged bilateral visits.

Hours after Trump's public pressure, the Indian prime-minister lifted the ban on hydroxychloroquine (and paracetamol) for neighboring countries and "to some nations who have been particularly badly affected by the pandemic" in order to clear "all existing orders" (Basu, 2020). Following the new directives, Indian exports of HCQ would take place under two categories: commercial supply and humanitarian aid. While one of the purposes of such move was to increase India's economic and political rivalry with China, which was under fire (particularly in the West) for its mismanagement and lack of transparency in handling the early stages of the outbreak (Mishra, 2020), the sudden rise of a 'hydroxychloroquine alliance' reinforced the strategies of some far-right populists across the world.

That explains those leaders' enthusiasm toward India's HCQ supplies. Trump celebrated Modi's decision on Twitter: "Extraordinary times require even closer cooperation between friends. Thank you India and the Indian people for the decision on HCQ. Will not be forgotten! Thank you Prime Minister @NarendraModi." (Trump, 2020d) The Indian prime-minister's response pointed to the populist radical right alliance: "Times like these bring friends closer. The India-US partnership is stronger than ever" (Modi, 2020b). To the U.S., Trump's remarks on possible retaliations following India's export ban, as well as Modi's immediate concession, have served to reaffirm American power - as well as Trump's steadfastness - in face of China's growing role in fighting the pandemic globally.

By advocating HCQ as a miraculous drug despite inconclusive clinical evidence (either for or against its use), Trump has reinforced his medical populist rhetoric that belittled the role of the 'elitist' scientific community and praised the 'conventional wisdom' of the average American. "So what do I know? I'm not a doctor. I'm not a doctor. But I have common sense" (Trump, 2020c), Trump bragged before the members of his own COVID-19 Task Force. Unsurprisingly, Trump's attitudes against science sowed discord among the administration's medical experts and led to a tug-of-war between the president and Dr. Fauci. To prove his point against research that alerted to the side effects and health risks of HCQ, Trump claimed he was taking the medicine preventively. "I take a pill every day. At some point I'll stop. What I'd like to is I'd like to have the cure and or the vaccine and that'll happen I think very soon. [...] It seems to have an impact, and maybe it does, maybe it doesn't" (Crowley, Thomas \& Haberman, 2020).

One must note, however, that Trump progressively abandoned his advocacy for HCQ as polls showed that the American public favored science, personified in Dr. Fauci, in fighting the COVID-19 as the number of deaths surpassed 100,000 in the U.S. by late May 2020 (Bump, 2020). In mid-June, the FDA revoked its emergency-use authorization for the two malaria drugs, claiming that it was "no longer reasonable to believe they may be effective in treating COVID-19" (Burton \& Hopkins, 2020). 


\subsection{Brazil}

As social networks and Whatsapp groups were flooded with vague accounts of alleged beneficial effects of HCQ for treating COVID-19 patients, demand for the medication boomed in Brazilian drugstores (Oliva, 2019). The day after Trump's public endorsement for the antimalarial drug, ANVISA included chloroquine and hydroxychloroquine in a list of controlled medicine (ANVISA, 2020). Bolsonaro's tweet on the anti-malarial drug as a "possible cure" for the novel coronavirus only added to the craze in Brazil, as searches for CQ and HCQ on Google soared and the number of Twitter mentions grew exponentially (Spagnuolo \& Orrico, 2020).

Fact-checking agency Aos Fatos showed how false reports and misinformation spread quickly on social networks after Bolsonaro's announcement, jumping from 8 to 45 percent of Brazil's most popular shared tweets. One of the most recurring lies claimed that hydroxychloroquine had proven efficacy in treating COVID-19 patients (Fávero \& Libório, 2020).

As in the United States, Bolsonaro has embarked on a daily journey to convince the public opinion of HCQ benefits, while bashing social distancing measures implemented by state governors and some big-city mayors. With his popularity hitting all-time lows as he entered his second year in office, Bolsonaro feared that the economic slowdown could undermine his short-term political capital even further (Vilardaga, 2020).

If HCQ was the lifeline to the president's political survival, he also wanted to reassemble his political base by resorting to economic populism to pit his supporters - especially small and large business people, and informal and autonomous workers, who were suffering the immediate effects of lockdown and distancing policies - against governors, lawmakers, and the mainstream press. By manifesting his indignation at state governors, who did not want to include religious activities as essential services, Bolsonaro also reached out to the powerful pentecostal leaders who have long supported him.

As a sign of faith in the miraculous powers of HCQ, the Brazilian president even displayed a box of Reuquinol by his side during his participation in the G-20 teleconference on March 26 (Andrade, 2020). That is the brand name of hydroxychloroquine manufactured by Apsen, whose CEO Renato Spallicci is an ardent supporter of the Bolsonaro administration and often defends the president on social media. Meanwhile, Bolsonaro requested the Brazilian Chamber of Foreign Trade to eliminate import taxes on chloroquine, azithromycin, and raw materials and ordered the Army Lab to manufacture 1 million doses of HCQ (Waltemberg \& Valeda, 2020).

It was not long before Bolsonaro's aggressive advocacy of the malaria drug sparked tensions in his own cabinet. Brazil's Health Minister Henrique Mandetta, who had received early praise for mobilizing Brazil's universal healthcare system (SUS, in the acronym in Portuguese) and supporting social distancing measures, began alerting the population of the risks of self-administering hydroxychloroquine as it could cause severe heart problems. Mandetta's defense of 'science' to guide policy-making in the COVID-19 fight came much to the president's chagrin, as Bolsonaro, like Trump, was waving the flag of "pandemic research exceptionalism". Bolsonaro responded as he did with other ministers who had also left the government: reaffirmed that he was the one in charge, isolated and challenged the minister in public events and meetings, while the president's supporters began attacking Mandetta's reputation on social media (Amado, 2020a). 
Between late March and early April, a vast network of pro-Bolsonaro public figures and lawmakers was formed around the promotion of HCQ, based on a partial research undertaken by the Prevent Senior operator (which sells health insurance for the elderly and has a hospital in São Paulo) that allegedly showed positive therapeutic results ${ }^{1}$. An op-ed written by Helio Beltrão (Beltrão, 2020), chair of the libertarian Brazilian Mises Institute, and an interview given by University of São Paulo virologist Paolo Zanotto to the far-right website Brasil Sem Medo quickly became staples among the president's supporters. Echoing Bolsonaro's narrative, their chief claim was that medical and scientific communities refrained from adopting HCQ protocols on ideological grounds. "If chloroquine was called [former president] Lula's drug, not Bolsonaro's or Trump's, I assure it would be a success", said Zanotto (Briguet, 2020a).

On April 4, Beltrão, one of the most vocal supporters of over-the-counter commercialization of HCQ, made a live broadcast with a Prevent Senior manager, Dr. Pedro Batista, Jr., and virology professor Zanotto (Beltrão, 2020b). They wanted to transform Prevent Senior's protocol into a national one, along the lines of what Bolsonaro had advocated from the start. They also took the opportunity to bash Health Minister Mandetta, who had authorized the supervised use of HCQ in patients with severe conditions, but was not willing to adopt the early use of the drug before more robust research came out.

The clash between the president and his top health advisor reached a peak on April 12, when Mandetta gave an interview on Globo TV Network - one of Bolsonaro's declared enemies - standing up for social isolation and complaining that Brazilians were lost as to they should listen to, the health officials or the president. By then, it seemed clear that the minister's days were counted. More specifically, it took four days for him to be sacked. But Mandetta did not leave office without making public that, the week before, Bolsonaro had secretly pressured him to sign a decree changing HCQ's prescription leaflet to include recommendations for COVID-19 (GZH, 2020). Together with the president were anesthesiologist Luciano Azevedo, who is known for his ultraconservative militancy, and immunologist Nise Yamaguchi, who also campaigned for hydroxychloroquine in the media, including some far-right websites (Briguet, 2020b).

Although those two pro-chloroquine doctors were among Mandetta's likely successors, Bolsonaro ended up appointing a former campaign advisor, physician and businessman Nelson Teich. He was considered a 'less controversial' name in the medical community and seemed to support some of Bolsonaro's ideas on how to tackle the crisis (Vargas \& Soares, 2020). However, Teich's reluctance to adopt HCQ in the national protocols without scientific backing and to speak against social distancing made him one of the shortest-lived ministers in Brazil's recent history, lasting for less than a month in office (Souza, Lima, Cardim \& Soares, 2020).

Tensions between the president and the Ministry of Health only allayed when Bolsonaro decided he would keep the interim minister, Army General Eduardo Pazzuello, to make sure hydroxychloroquine would be included in the national treatment protocol for all COVID-19 patients. Besides adopting a new protocol on May 20, which came under heavy congressional protest, Pazzuello appointed 13

${ }^{1}$ The study has been described by French geneticist Gaetan Burgio as follows: "this is really really bad study and awful science" (Burgio, 2020). 
Army officers to top positions in the ministry. Neither him nor his direct aides have specific medical training or previous experience in health policy-making (Amado, 2020b).

A last note on Bolsonaro's medical populism refers to the religious underpinnings of his HCQ approach. Bolsonaro's appeal to Christians has always been an important element of his popularity, which may explain his permanent reference to Biblical verses and his close relationship with Evangelical leaders, some of whom have been staunch chloroquine advocates (Casarões, 2020). Unsurprisingly, disinformation campaigns on the COVID-19 pandemic have either begun or gained momentum in religious networks (Machado et al., 2020).

The religious leanings of Bolsonaro's medical populist performance has both domestic politics and foreign policy implications. After being tested positive for COVID-19, on July 7, president Bolsonaro announced he was taking chloroquine as part of his treatment. Over that day, he mentioned the medicine 17 times as a potential cure for the disease. In the weeks that followed, he appeared a few times lifting a box of chloroquine before huge crowds, which hailed the drug as some sort of religious symbol - reinforcing Bolsonaro's own messianic character (Sakamoto, 2020).

Finally, on the global stage, the Brazilian president followed Trump's steps and thanked prime-minister Modi on his social networks after the Indian prime-minister lifted the export ban. Bolsonaro's letter of gratitude to the Indian government invoked religious elements that speak to both leaders' populist strategies in an unusual comparison between the Hindu epic Ramayana and the Bible: "Just as Lord Hanuman brought the holy medicine from the Himalayas to save the life of Lord Rama's brother Lakshmana, and Jesus healed those who were sick and restored the sight to Bartimeu, India and Brazil will overcome this global crisis by joining forces and sharing blessings for the sake of all peoples" (The Hindu, 2020). A few months later, on May 31, Bolsonaro again expressed Brazil's gratitude for the U.S. act of solidarity. No longer interested in touting HCQ, Trump had decided to deliver two million doses of the medicine 'to the Brazilian people' (Ministério das Relações Exteriores, 2020).

\section{FINAL REMARKS}

Even though the use of hydroxychloroquine has become an important instrument of far-right populists all across the globe, it has played different domestic and international roles. Thanks to the power-concentrating nature of presidents (as opposed to the political constraints of the parliamentary systems of India, Israel, or Hungary), Trump and Bolsonaro have been able to fully exert the strategies and performances of medical populism. They have persistently touted HCQ in spite of feeble scientific evidence, in an attempt to garner and secure political support by pitting the masses (or 'the people') against doctors, mainstream scientists, and public health authorities (or 'the establishment'). Hydroxychloroquine seemed like the perfect populist tool not only because of promising prospects, but especially due to the fact that it emerged from, and helped foster, a far-reaching alt-science movement, in an unusual alliance between Silicon Valley entrepreneurs, the far-right media, and maverick scientists such as Didier Raoult, whose views on HCQ have validated efforts by local agents, such as Brazil's Prevent Senior operator and several Bolsonaro supporters.

The urge in seeking a solution for the COVID-19 outbreak and the populist tendency to offer simple solutions to complex problems led leaders in Brazil and the U.S. to run counter to expert advice, as it became clear in the clashes between Trump and Dr. Anthony Fauci and Bolsonaro and 
RAP | The hydroxychloroquine alliance: how far-right leaders and alt-science preachers came together to promote a miracle drug

his two health ministers, Mandetta and Teich, with dramatic policy implications. It also led those leaders to form an overarching alliance of far-right influencers, businesspeople and leaders, which has also included India, whose prime-minister wanted to position himself as the world's key medicine supplier to fight the global pandemic, and Israel, whose prime-minister used HCQ as a sign of his steadfast leadership as he tried to form a new government. 


\section{REFERENCES}

Abdelal, R. (2020, May 28). Analytics. Retrieved from https://valdaiclub.com/a/highlights/populism-thepandemic-and-the-crisis/

Agência Nacional de Vigilância Sanitária. (2020, March 20). Resolução de diretoria colegiada - RDC no 351, de 20 de março de 2020. Retrieved from http://portal. anvisa.gov.br/documents/33868/3233591/72++ RDC+N\%C2\%BA+351-2020-DOU.pdf/bf7b1b3d951a-4037-8fb8-38225319f8f9

Aljazeera. (2020, May 24). Netanyahu: Corruption trial an attempt to "depose a strong PM". Retrieved from https://www.aljazeera.com/news/2020/05/ netanyahu-arrives-court-corruption-trialprotests-200524115748118.html

Andrade, H. (2020, March 26). Bolsonaro mostra remédio feito com hidroxicloroquina em reunião do G20. Retrieved from https://noticias.uol.com. $\mathrm{br} / \mathrm{saude} / \mathrm{ultimas}-$ noticias/redacao/2020/03/26/ bolsonaro-mostra-remedio-feito-comhidroxicloroquina-em-reuniao-do-g20.htm

Balasubramanian, J. S. D. (2020, April 14). Why Did President Trump Request India For Hydroxychloroquine? Retrieved from https:// www.forbes.com/sites/saibala/2020/04/13/ why-did-president-trump-request-india-forhydroxychloroquine/\#1f2a8ee770bb+

Basu, N. (2020, April 07). India partially lifts ban on export of hydroxychloroquine to help US, others fight Covid-19. Retrieved from https://theprint. in/diplomacy/india-partially-lifts-ban-on-exportof-hydroxychloroquine-hours-after-trumpsthreat/396792/

Beltrão, H. (2020a, March 25). Liberem a hidroxicloroquina. Retrieved from https://www. folha.uol.com.br/colunas/helio-beltrao/2020/03/ liberem-a-hidroxicloroquina.shtml

Beltrão, H. [@heliobeltrao]. (2020b, April 4). Pessoal, o Pedro Batista Jr, da Prevent Senior TAMBÉM ESTARÁ NA LIVE em 45min! Nunca fiz uma live que prometa tanta informação relevante. Retrieved from https://twitter.com/heliobeltrao/ status/1246486196601135110

Bloomberg, C. A. (2020, April 07). India Partially Lifts Export Ban on Potential Coronavirus Treatment After Trump Call. Retrieved from https://time. com/5816617/india-lifts-hydroxychloroquineexport-ban/

Bolsonaro, J. M. [@jairbolsonaro]. (2020, March 21). Hospital Albert Einstein e a possível cura dos pacientes com o Covid-19. Retrieved from https://twitter.com/ jairbolsonaro/status/1241434576049840130

Briguet, P. (2020a, April 05). Cloroquina é o remédio para vencer a epidemia. Retrieved from https:// brasilsemmedo.com/cloroquina-e-o-remedio-paravencer-a-epidemia/

Briguet, P. (2020b, April 05). Dra. Nise e a batalha para salvar o Brasil do vírus. Retrieved from https:// brasilsemmedo.com/dra-nise-e-a-batalha-parasalvar-o-brasil-do-virus/

Bump, P. (2020, April 24). The rise and fall of Trump's obsession with hydroxychloroquine. Washington Post. Retrieved from https://www.washingtonpost.com/ gdpr-consent/?next_url=https $\% 3 \mathrm{a} \% 2 \mathrm{f} \% 2 \mathrm{fwww}$. washing tonpost.com $\% 2$ fpolitics $\% 2$ f $2020 \% 2 \mathrm{f}$ $04 \% 2$ f $24 \% 2$ frise-fall-trumps-obsession-withhydroxychloroquine $\% 2 \mathrm{f}$

Burgio, G. [@GaetanBurgio].(2020,April 18).Another study on \#Hydroxycloroquine efficacy in \#COVID19 patients from a Brazilian team has been shared widely this evening. Retrieved from https://twitter.com/ GaetanBurgio/status/1251476181989208066

Burton, T. M., Hopkins, J. (2020, June 16). FDA Pulls Emergency Covid-19-Use Approval for Hydroxychloroquine, Taken by Trump. WSJ. Retrieved from https://www.wsj.com/articles/ fda-withdraws-emergency-use-authorization-forhydroxychloroquine-for-covid-19-11592238129

Casarões, G. (2020). Religião e poder: a ascensão de um projeto de nação evangélica no Brasil? Revista Interesse Nacional, 13(49), 9-16.

Caulfield, T. (2020, April 19). Dr. Oz's hydroxychloroquine advocacy seduces Trump as coronavirus wellness woo surges. $\mathrm{NbcNews}$. Retrieved from https://www.nbcnews.com/think/opinion/droz-s-hydroxychloroquine-advocacy-seduces-trumpcoronavirus-wellness-woo-ncna1185596

Crowley, M., Thomas, K., \& Haberman, M. (2020, April 06). Ignoring Expert Opinion, Trump Again Promotes Use of Hydroxychloroquine. Retrieved from https:/www.nytimes.com/2020/04/05/us/politics/ trump-hydroxychloroquine-coronavirus.html 
Economic Times. (2020, April 17). India sending hydroxychloroquine to 55 coronavirus-hit countries. Retrieved from https://economictimes.indiatimes. $\mathrm{com} /$ news/politics-and-nation/india-sendinghydroxychloroquine-to-55-coronavirus-hitcountries/articleshow $/ 75186938 . \mathrm{cms}$ ?from $=\mathrm{mdr}+$

Edney, A. (2020, April 1). Drugs Trump Touted for Covid-19 Treatment Added to Shortage List. Retrieved from https://www.bloomberg.com/tosv2. html? vid=\&uuid=3bc5f0d0-a448-11 ea-89ed-d 1 b47852f21 a\&url=L25ld3MvYXJ0aWNsZXMvM jAyMC0wNC0wMS9kcnVncy10cnVtcC10b3V0 ZWQtZm9yLWNvdmlkLTE5LXRyZWF0bWV udC1hZGRlZC10bylzaG9ydGFnZS1saXN0

Efrati, I. (2020, March 27). Israel preparing to use unapproved medication to treat coronavirus Israel News. Retrieved from https://www.haaretz. com/israel-news/.premium-israel-preparingto-use-unapproved-medication-to-treatcoronavirus- 1.8712940

Engber, D. (2017, October 16). The Grandfather Of Alt-Science. Five ThirtyEight. Retrieved from https:// fivethirtyeight.com/features/the-grandfather-of-altscience/

Fávero, B., \& Libório, B. (2020, April 07). Como a desinformação sobre cloroquina se multiplicou no Twitter após aval de Bolsonaro à droga. Retrieved from https://www.aosfatos.org/noticias/comodesinformacao-sobre-cloroquina-se-multiplicouno-twitter-apos-aval-de-bolsonaro-droga/

Flaherty , A., \& Phelps, J. (2020, March 20). Fauci throws cold water on Trump's declaration that malaria drug chloroquine is a "game changer". Retrieved from https://abcnews.go.com/Politics/fauci-throwscold-water-trumps-declaration-malaria-drug/ story? $\mathrm{id}=69716324$

Gabler, E., \& Keller, M. (2020, May 20). Prescriptions Surged as Trump Praised Drugs in Coronavirus Fight. Retrieved from https://www. nytimes.com/2020/04/25/us/coronavirus-trumpchloroquine-hydroxychloroquine.html

Gautret, P., Lagier, J. C., Parola, P., Hoang, V.T., Medde, L. ... Raoulta, D. (2020, July). Hydroxychloroquine and azithromycin as a treatment of COVID-19: results of an open-label non-randomized clinical trial. International Journal of Antimicrobial Agents, 56(1), 105949. Retrieved from https://doi.org/10.1016/j. ijantimicag.2020.105949
Gogarty, K., \& Walker, A. (2020, April 16). A comprehensive guide to Fox's promotion of hydroxychloroquine and chloroquine. Retrieved from https://www.mediamatters.org/coronaviruscovid-19/comprehensive-guide-foxs-promotionhydroxychloroquine-and-chloroquine

Goodman, M. (2019). Return to the Regulatory Dark Ages. Retrieved from https://store.counterpunch. org/wp-content/uploads/2019/08/vol-26-no-3.pdf

Gorski, D. [@gorskon]. (2020, April 17).Bloody hell. The sheer volume of crappy studies of \#hydroxychloroquine for \#COVID19 is impossible to keep up with!. Retrieved from https://twitter.com/ gorskon/status/1251270530331824131?s=20

Greer, S. L. (2017). Medicine, public health and the populist radical right. Journal of the Royal Society of Medicine, 110(8), 305-308.

Grens, K. (2020, April 9). Journal Publisher Concerned over Hydroxychloroquine Study. Retrieved from https://www.the-scientist.com/ news-opinion/journal-publisher-concerned-overhydroxychloroquine-study- 67405

Gupta, S. (2020, April 07). In PM Modi's hydroxychloroquine export order, a Covid-19 message to the world - world news. Retrieved from https://www.hindustantimes.com/worldnews/in-modi-s-hydroxychloroquine-exportorder-a-covid-19-message-to-the-world/ story-ySR32J4ccmcnhrCzARv3jI.html

GZH. (2020, May 21). Bolsonaro queria alterar bula da cloroquina, afirma Mandetta. Retrieved from https:// gauchazh.clicrbs.com.br/politica/noticia/2020/05/ bolsonaro-queria-alterar-bula-da-cloroquinaafirma-mandetta-ckagti0dw005y015nzrovz206.html

Harkov, B. L. (2020, March 28). MPs from across Europe seek Israel's advice on tackling coronavirus. Retrieved from https://www.jpost.com/israel-news/ mps-from-across-europe-seek-israels-advice-ontackling-coronavirus-622739

Harris, J. (2020, March 18). The experts are back in fashion as Covid-19's reality bites. Retrieved from https://www.theguardian.com/commentisfree/2020/ mar/15/experts-fashion-covid-19-reality-bitestrump-johnson

i24NEWS. (2020, March 19). Israel: Netanyahu announces seven-day state of emergency over 
coronavirus. Retrieved from https://www.i24news. tv/en/news/israel/1584645604-israel-netanyahuannounces-seven-day-state-of-emergency-overcoronavirus

ISAC. (2020, April 03). Statement on IJAA paper International Society of Antimicrobial Chemotherapy. Retrieved from https://www.isac.world/news-andpublications/official-isac-statement

Kupferschmidt, K. (2020, June 09). Three big studies dim hopes that hydroxychloroquine can treat or prevent COVID-19. Science. Retrieved from https:// www.sciencemag.org/news/2020/06/three-bigstudies-dim-hopes-hydroxychloroquine-can-treator-prevent-covid-19

Lasco, G. (2020). Medical populism and the COVID-19 pandemic. Global Public Health, 10, 1417-1429.

Lasco, G., \& Curato, N. (2019). Medical populism. Social Science \& Medicine, 221, 1-8.

London, A. J., \& Kimmelman, J. (2020, May 01). Against pandemic research exceptionalism. Science. Retrieved from https://science.sciencemag.org/ content $/ 368 / 6490 / 476$.full

Ministério da Saúde. (2020, March 25). Cloroquina poderá ser usada em casos graves do coronavírus. Retrieved from https://www.saude.gov.br/noticias/ agencia-saude/46601-cloroquina-podera-ser-usadaem-casos-graves-do-coronavirus

Ministério das Relações Exteriores. (2020, May 31). Joint Statement from the Governments of the United States of America and the Federative Republic of Brazil regarding Health Cooperation. Nota 62. Brasília, DF: Author.

Mishra, A. (2020, April 20). Hydroxychloroquine: India proves a friend in need is a friend indeed. The Times of India. Retrieved from https:// timesofindia.indiatimes.com/blogs/always-right/ hydroxychloroquine-india-proves-a-friend-inneed-is-a-friend-indeed/

Modi, N. [@narendramodi]. (2020a, April 04). Had an extensive telephone conversation with President @realDonaldTrump.We had a good discussion, and agreed to deploy the full strength of the India-US partnership to fight COVID-19. Retrieved from https://twitter.com/narendramodi/ status/1246431862148534277
Modi, N. [@narendramodi]. (2020b, April 09).Fully agree with you President @realDonaldTrump. Times like these bring friends closer. The India-US partnership is stronger than ever. Retrieved from https://twitter. com/narendramodi/status/1248110109487591424

Morath, E. (2020, June 01). How Many U.S. Workers Have Lost Jobs During Coronavirus Pandemic? There Are Several Ways to Count. The Wall Street Journal. Retrieved from https://www.wsj.com/ articles/how-many-u-s-workers-have-lost-jobsduring-coronavirus-pandemic-there-are-severalways-to-count-11591176601

Mudde, C. (2020, April 1). Will the coronavirus "kill populism"? Don't count on it. The Guardian. Retrieved from https://www.theguardian.com/ commentisfree $/ 2020 / \mathrm{mar} / 27 /$ coronaviruspopulism-trump-politics-response

Mudde, C., \& Kaltwasser, R. C. (2017). Populism: A Very Short Introduction (Very Short Introductions) (2nd ed.). Oxford, UK: Oxford University Press.

Müller, J. (2020, April 07). How Populists Will Leverage the Coronavirus Pandemic. World Politics Review. Retrieved from https://www. worldpoliticsreview.com/articles/28663/howpopulists-will-leverage-the-coronavirus-pandemic

Musk, E. [@elonmusk]. (2020, March 06). The coronavirus panic is dumb. Retrieved from https:// twitter.com/elonmusk/status/1236029449042198528

Netanyahu, B. (2020, April 11). Three Enormous Shipments of Anti-Corona Supplies Land in Israel. Retrieved from https://www.gov.il/en/departments/ news/spoke_medical110420

Netanyahu, B. [@IsraelPM]. (2020, April 09). Thank you, my dear friend @narendramodi, Prime Minister of India, for sending Chloroquine to Israel. Retrieved from https://twitter.com/israelipm/ status/1248319047785119750

Nguyen, T. (2020, April 04). How a chance Twitter thread launched Trump's favorite coronavirus drug. Politico. Retrieved from https://www.politico.eu/ article/how-a-chance-twitter-thread-launchedtrumps-favorite-coronavirus-drug/

O'Connor, C., \& Weatherall, J. O. (2020, May 04). Hydroxychloroquine and the Political Polarization of Science. Boston Review. http://bostonreview.net/ science-nature-politics/cailin-oconnor-james-owenweatherall-hydroxychloroquine-and-political 
Oliva, G. (2020, March 21). Coronavírus: desaparecimento da cloroquina das farmácias do Rio preocupa pacientes usuários de medicamentos. O Globo. Retrieved from https:// oglobo.globo.com/sociedade/coronavirus-servico/ coronavirus-desaparecimento-da-cloroquina-dasfarmacias-do-rio-preocupa-pacientes-usuarios-demedicamentos-24318959

Palmer, E. (2020, March 24). FDA frees India's Ipca from import ban so it can ship unproven COVID-19 treatments. Retrieved from https://www. fiercepharma.com/manufacturing/fda-lifts-banso-india-s-ipca-so-can-ship-unproven-covid-19treatments

Paracha, N. (2020, April 06). Populism the first ideological casualty? Daily Pioneer. Retrieved from https://www.dailypioneer.com/2020/columnists/ populism-the-first-ideological-casualty-.html

Parmet, W. E. (2010). Pandemics, Populism and the Role of Law in the H1N1 Vaccine Campaign. St. Louis U. J. Health L. \& Policy, 4, 113-156.

Prevent Senior Institute. (2020, April 17). Empirical treatment with hydroxychloroquine and azithromycin for suspected cases of COVID-19 followed-up by telemedicine. Retrieved from https://static.poder360. com.br/2020/04/2020.04.15-journal-manuscriptfinal.pdf

Raoult, D. (2011, December 12). Et si Darwin sétait trompé... Retrieved from https://www. lepoint.fr/debats/et-si-darwin-s-etaittrompe-12-12-2011-1406407_2.php

Raoult, D. (2013, October 08). Les prédictions climatiques sont absurdes! Retrieved from https://www.lepoint.fr/invites-du-point/ didier_raoult/les-predictions-climatiques-sontabsurdes-08-10-2013-1740365_445.php

Raoult, D. [@raoult_didier]. (2020, April 18).Un manuscrit dont la publication devrait faire parler: expérimentation de la bithérapie $H C Q+A Z$ au Brésil. Retrieved from https://twitter.com/raoult_didier/ status/1251450740641542144

Reuters. (2020a, June 11). India lifts export ban on Trump-touted drug hydroxychloroquine U.S. Retrieved from https://www.reuters.com/article/ us-health-coronavirus-india-pharmaceutic/ india-lifts-export-ban-on-trump-touted-drughydroxychloroquine-idUSKBN23I0QP
Reuters. (2020b, April 03). Hungary's Alkaloida says it can mass produce hydroxychloroquine for coronavirus use: media. U.S. Retrieved from https://www.reuters. com/article/us-health-coronavirus-hungarymedicine/hungarys-alkaloida-says-it-can-massproduce-hydroxychloroquine-for-coronavirus-usemedia-idUSKBN21L12F

Sakamoto, L. (2020, July 07). Cena de culto à cloroquina mostra que ela se tornou símbolo do bolsonarismo. UOL Notícias. Retrieved from https://noticias.uol.com.br/colunas/ leonardo-sakamoto/2020/07/20/cena-de-cultoa-cloroquina-mostra-que-ela-se-tornou-simbolodo-bolsonarismo.htm

Sanches, M. (2020, May 30). À frente da SpaceX e ex-queridinho da internet, Elon Musk se aproxima da direita de Trump e Bolsonaro. BBC News Brasil. Retrieved from https://www.bbc.com/portuguese/ internacional-52860772

Sayare, S. (2020, May 22). He Was a Science Star. Then He Promoted a Questionable Cure for Covid-19. The New York Times. Retrieved from https://www.nytimes.com/2020/05/12/magazine/ didier-raoult-hydroxychloroquine.html

Souza, R., Lima, B., Cardim, M. E., \& Soares, I. (2020, May 16). Uso da cloroquina no tratamento da covid-19 provocou saída de Teich. Correio Braziliense. Retrieved from https://www.correiobraziliense. com.br/app/noticia/politica/2020/05/16/interna_ politica,855426/uso-da-cloroquina-no-tratamentoda-covid-19-provocou-saida-de-teich.shtml

Srivastava, M. (2020, April 22). How Israel's Netanyahu secured his political survival. Financial Times. Retrieved from https://www.ft.com/content/ cf76fc6f-486e-49c2-a004-242484b0078c

Suneja, K. (2020, April 05). Blanket ban on export of anti-malarial drug hydroxychloroquine, government withdraws exemptions. The Times of India. Retrieved from https://economictimes. indiatimes.com/news/economy/foreign-trade/ blanket-ban-on-export-of-anti-malarial-drughydroxychloroquine-government-withdrawsexemptions/articleshow/74987181.cms?from $=\mathrm{mdr}+$

The Hindu. (2020, April 09). Brazilian President invokes Ramayana while seeking hydroxychloroquine from India. Retrieved from https://www.thehindu. com/news/international/brazilian-prez-invokesramayana-while-seeking-hydroxychloroquinefrom-india/article31295486.ece 
Traiman, A. (2020, April 22). It's a unity of 2, but really only 1 winner. The Jewish Star. Retrieved from https://www.thejewishstar.com/stories/its-a-unityof-2-but-really-only-1-winner,19055

Tribune News Service. (2020, April 22). Coronavirus: India readying rapid response teams for Bangladesh, Bhutan, Sri Lanka and Afghanistan. Retrieved from https://www.tribuneindia.com/news/nation/ coronavirus-india-readying-rapid-responseteams-for-bangladesh-bhutan-sri-lanka-andafghanistan-74599

Trump, D. J. (2020a, March 28). Remarks by President Trump, Vice President Pence, and Members of the Coronavirus Task Force in Press Briefing. The White House. Retrieved from https://www.whitehouse.gov/ briefings-statements/remarks-president-trumpvice-president-pence-members-coronavirus-taskforce-press-briefing-13/

Trump, D. J. (2020b, April 05). Remarks by President Trump, Vice President Pence, and Members of the Coronavirus Task Force in Press Briefing. The White House. Retrieved from https://www.whitehouse.gov/ briefings-statements/remarks-president-trumpvice-president-pence-members-coronavirus-taskforce-press-briefing-19/

Trump, D. J. (2020c, April 06). Remarks by President Trump, Vice President Pence, and Members of the Coronavirus Task Force in Press Briefing. The White House. Retrieved from https://www.whitehouse.gov/ briefings-statements/remarks-president-trumpvice-president-pence-members-coronavirus-taskforce-press-briefing-20/

Trump, D. J. (2020d, April 07). Remarks by President Trump, Vice President Pence, and Members of the Coronavirus Task Force in Press Briefing. The White House. Retrieved from https://www.whitehouse.gov/ briefings-statements/remarks-president-trumpvice-president-pence-members-coronavirus-taskforce-press-briefing-21/

Trump, D. J. [@realDonaldTrump]. (2020a, March 21). HYDROXYCHLOROQUINE \& AZITHROMYCIN, taken together, have a real chance to be one of the biggest game changers in the history of medicine. The FDA has moved mountains - Thank You! Retrieved from https://twitter.com/ realdonaldtrump/status/1241367239900778501
Trump, D. J. [@realDonaldTrump]. (2020b, April 08). Extraordinary times require even closer cooperation between friends. Thank you India and the Indian people for the decision on HCQ. Will not be forgotten! Thank you Prime Minister@ NarendraModi. Retrieved from https://twitter.com/ realDonaldTrump/status/1247950299408498693

Vargas, M. \& Soares, J. (2020, April 15). Veja quem são os cogitados para substituir Mandetta na Saúde. Terra Notícias. Retrieved from https://www.terra. com.br/noticias/coronavirus/veja-quem-sao-oscogitados-para-substituir-mandetta-na-saude,clfb 93e71e48786e3d8a510bf53fbad5tuo65log.html

Velasco, A. (2020, May 05). The Populists' Pandemic. Retrieved from https://www.project-syndicate.org/ commentary/covid19-could-strengthen-or-weakenpopulists-by-andres-velasco-2020-05

Vidale, G. (2020, April 27). Conep suspende estudo da Prevent Senior com hidroxicloroquina. Veja. Retrieved from https://veja.abril.com.br/saude/ conep-suspende-estudo-da-prevent-senior-comhidroxicloroquina/

Waldman, S. C. (2017, March 29). House Science Committee Calls on Alt-Science to Drive Policy. Scientific American. Retrieved from https://www. scientificamerican.com/article/house-sciencecommittee-calls-on-alt-science-to-drive-policy/

Waltemberg, G., \& Valeda, R. (2020, April 06). Empresário que produz a cloroquina é militante bolsonarista. Metrópoles. Retrieved from https:// www.metropoles.com/brasil/politica-brasil/ empresario-que-produz-a-cloroquina-e-militantebolsonarista

Washington Post. (2020, April 09). Ingraham and Hannity have been talking about hydroxychloroquine twice as much as any other show. Retrieved from https://www.washingtonpost.com/gdprconsent/?next_url=https\%3a\%2f\%2fwww. washingtonpost.com $\% 2$ fpolitics $\% 2$ f2020\%2f04 $\% 2$ f09\%2fingraham-hannity-have-been-talkingabout-hydroxochloroquine-twice-much-any-othershow $2 \mathrm{f}$

Wessel, L. (2020, June 23). 'It's a nightmare.' How Brazilian scientists became ensnared in chloroquine politics. Science. Retrieved from https://www. sciencemag.org/news/2020/06/it-s-nightmare-how- 
RAP | The hydroxychloroquine alliance: how far-right leaders and alt-science preachers came together to promote a miracle drug

brazilian-scientists-became-ensnared-chloroquinepolitics

White House. (2020, March 03). 30 days to slow the spread. Retrieved from https://www.whitehouse.gov/ wp-content/uploads/2020/03/03.16.20_coronavirusguidance_8.5x11_315PM.pdf

World Health Organization. (2020, March 13). Informal consultation on the potential role of chloroquine in the clinical management of COVID 19 infection. Retrieved from https://www.who.int/
blueprint/priority-diseases/key-action/RD-Blueprintexpert-group-on-CQ-call-Mar-13-2020.pdf?ua=1

Yasgur, B. S. (2020, May 22). Hydroxychloroquine Has No Benefit, "Only Risks" in COVID-19. Retrieved from https://www.medscape.com/viewarticle/931061

Zabala, S. (2020, April 21). The coronavirus pandemic is a threat to populist strongmen. $A l$ Jazeera. Retrieved from https://www.aljazeera.com/ indepth/opinion/coronavirus-pandemic-threatpopulist-strongmen-200421105729756.html

\section{Guilherme Casarões}

https://orcid.org/0000-0002-8887-6538

Ph.D. in Political Science (USP) and Associate Professor at FGV EAESP. E-mail: casaroes@gmail.com

\section{David Magalhães}

https://orcid.org/0000-0002-2956-3646

Ph.D. in International Relations (Programa San Tiago Dantas) and Adjunct Professor at FAAP and PUC-SP.

E-mail: david.dvdmg@gmail.com 